\title{
KEDUDUKAN HAK ATAS TANAH WARIS WARGA NEGARA INDONESIA YANG BERPINDAH KEWARGANEGARAAN
}

\author{
Kadek Hapsari Ika Palupi, Ida Ayu Putu Widiati, I Wayan Arthanaya \\ Fakultas Hukum Universitas Warmadewa, Denpasar - Bali, Indonesia
}

\begin{abstract}
Abstrak
Status kewarganegaraan seseorang akan berdampak pada perolehan jaminan hak dari suatu negara. WNI berhak memperoleh hak milik atas tanah di Indonesia tapi tidak bagi WNI yang berpindah kewarganegaraan, berbeda halnya bilamana memperoleh hak milik atas tanah karena pewarisan. Berkenaan dengan itu maka rumusan masalahnya: 1) Bagaimana pengaturan hak atas tanah waris di Indonesia berdasarkan KUHPerdata?) Bagaimana kedudukan hak atas tanah waris WNI yang berpindah kewarganegaraan? Penelitian ini merupakan penelitian hokum normatif dengan pendekatan perundang- undangan dan konseptual. Hasil dari penelitian ini adalah pengaturan hak atas tanah waris di Indonesia yaitu berlakunya tiga Hukum Waris, yaitu Hukum Waris Adat, Hukum Waris Islam dan Hukum Waris KUH Perdata. Berdasarkan pada Hukum Waris KUHPerdata ialah terdapat golongan-golongan yang membedakan ahli waris serta surat wasiat yang isinya tidak boleh bertentangan dengan legitieme portie (bagian mutlak) dan berkaitan dengan warisnya ialah tanah, terdapat aturan lain yang perlu dipatuhi yaitu Undang-undang RI Nomor 5 Tahun 1960 tentang Peraturan Dasar Pokok-pokok Agraria. Kedudukan tanah waris WNI yang berpindah kewarganegaraan adalah jatuh kepada negara bilamana ia tidak mengalihkan tanah warisnya dalam kurun waktu satu tahun sejak ia berpindah kewarganegaraan.
\end{abstract}

Kata Kunci: Hak; Perubahan Kewarganegaraan; Tanah Waris; WNI

\begin{abstract}
A person's citizenship status has an impact on obtaining guarantees of rights from the state. Indonesian citizens are granted the right to obtain ownership rights to land in Indonesia, but not to those who have changed their citizenship status. The case is different if a citizen acquires the rights of ownership over land due to inheritance. In this regard, this study addresses two questions: 1) how is the inheritance rights in Indonesia based on the Civil Code regulated?) What is the position of inheritance rights of Indonesian a citizen who has changed his/her citizenship status? This study uses a normative legal research method with a statutory approach and a conceptual approach to achieve these goals. The results indicate that the regulation of inheritance rights in Indonesia is realized through the enactment of three types of inheritance law, namely Customary Inheritance Law, Islamic Inheritance Law and Civil Code Inheritance Law. In the Civil Code of Inheritance Law there are groups that distinguish between heirs and wills whose contents shall not conflict with legitieme portie (absolute part) and shall relate to its inheritance which is land. Then, there are other rules that need to be obeyed namely Indonesian Republic Law Number 5 of 1960 concerning Basic Regulations of Agrarian Principles. The status of ownership rights of land of an Indonesian citizen who has changed his/her citizenship status transfers to the state if the said citizen does not transfer the status of his/her land inheritance within one year from his transfer of citizenship.
\end{abstract}

Keywords: Rights of Ownership; Change of Citizenship; Land of Inheritance; Indonesian Citizen

\section{PENDAHULUAN}

Tanah merupakan sumber kesejahteraan, kemakmuran serta kehidupan yang memiliki peranan penting bagi makhluk yang hidup di dunia ini. Hal ini merupakan tanggung jawab nasional dalam mewujudkan kesejahteraan dan kemakmuran rakyat sesuai dengan Pasal 33 Ayat (3) Undang-Undang Dasar Negara Republik Indonesia Tahun 1945 yang mencantumkan bahwa "Bumi, air dan kekayaan alam yang terkandung di dalamnya dikuasai oleh negara dan dipergunakan untuk sebesar-besarnya kemakmuran rakyat". Undang-undang Republik Indonesia Nomor 5 Tahun 1960 tentang Peraturan Dasar Pokok-pokok Agraria yang selanjutnya disebut dengan UUPA diterbitkan atau dikeluarkan sebagai bentuk peraturan khusus yang mengatur tentang tanah dan hak atas tanah yang dapat 
diperoleh. Hak atas tanah itu meliputi: Hak Milik, Hak Guna Bangunan, Hak Guna Usaha, Hak Pakai, dan Hak Sewa Untuk Bangunan (Santoso, 2015: 37).

Hak milik hanya dapat dimiliki oleh warga negara Indonesia sesuai dengan Pasal 1 ayat (1) UUPA. Hak milik ini adalah hak turun temurun yang dapat dialihkan kepada pihak lain melalui perbuatan hukum seperti jual-beli, tukar menukar, hibah atau pemberian wasiat. Pemberian wasiat atau warisan baik harta kekayaan material maupun inmaterial yang bergerak maupun yang tidak bergerak diatur dalam hukum waris. Hukum waris yang dianut oleh Indonesia ada 3 yakni, hukum waris adat, hukum waris Islam, dan hukum waris KUHPerdata. Harta bergerak untuk property seperti tanah seorang ahli waris harus mendapatkan legalitas hak atas tanah warisan yang diperolehnya di Kepala Kantor Pertanahan. Tanpa adanya legalitas tersebut, maka tanah waris dinyatakan tidak sah dimata hukum.

Warga negara asing yang menetap di suatu negara namun bukan termasuk daklam warga negara dan jika tidak terdaftar secara resmi sebagai warga negara yang memiliki tujuan bisnis, pendidikan, liburan maupun hal lainnya tersebut dapat memperoleh hak atas tanah yakni hak pakai serta hak sewa bangunan. Terdapat peraturan yang harus dipenuhi oleh WNI yang berpindah kewarganegaraan dan memiliki waris tanah di Indonesia yakni diatur dalam Pasal 1 ayat (3) UUPA. Dalam pasal ini mengatur mengenai jangka waktu 1 tahun sejak diperolehnya hak milik atas tanah yang diberikan kepada pewaris untuk mengalihkannya kepada subjek yang memenuhi syarat atau dapat melakukan penjualan atas tanah yang diwarisi.

Terkait hak atas tanah dalam kaitannya dengan warisan penelitian ini bukanlah penelitian yang pertama. Sejumlah kajian telah dialamatkan pada telaah mengenai masalah tersebut setidaknya dalam dua dekade terakhir. Terkait pelaksanaan pendaftaran peralihan hak milik atas tanah karena pewarisan serta kendala yang dihadapi dalam pelasksanaan kegiatan tersebut serta solusinya telah dikaji dan mengungkap bahwa proses pelaksanaan pendaftaran peralihan hak milik atas tana karena pewarisan di Indonesia berdasarkan hukum ialah baik kecuali kekurangan dalam bentuk administrasi-administrasi yang diperlukan (Sajad, 2008). Terkait hak pakai atas rumah hunian warga Negara asing dalam perkawinan campuran tanpa perjanjian juga pernah diluncurkan melalui kajian ilmiah (Winarta dkk., 2017). Hak ahli waris berkewarganegaraan asing terhadap harta warisan berupa tanah juga telah diteliti dari segi hukum (Paramita et al., 2018). Mengenai akibat hukum perkawinan campuran terhadap harta perkawinan di Denpasar juga telah diungkap melalui kajian ilmiah (Widanarti, 2018). Yang lain ialah terkait proses peralihan hak milik atas tanah karena pewarisan dalam perkawinan campuran. Kajian ilmiah juga telah mengungkap terkait soal ini (Irvan dkk., 2019). Di antara kajiankajian sebelumnya, pembahasan tentang hak atas tanah waris warga negara Indonesia yang berpindah kewarganegaraan belum diluncurkan. Padahal hal tersebut telah menjadi fenomena yang melibatkan sentuhan hukum.

Uraian di atas memicu pelaksanaan penelitian ini. Oleh karena itu kajian ini membahas dua hal: (1) Bagaimana pengaturan hak atas tanah waris di Indonesia berdasarkan KUHPerdata? (2) Bagaimana kedudukan hak atas tanah waris WNI yang berpindah kewarganegaraan? Tujuan penelitian penelitian ialah untuk mengetahui tentang pengaturan hak atas tanah waris di Indonesia, dan untuk mengetahui, meneliti dan menemukan konsep hukum berkaitan dengan kedudukan hak atas tanah waris WNI yang berpindah kewarganegaraan.

\section{METODE PENELITIAN}

Tipe penelitian yang dipergunakan dalam penelitian ini merupakan penelitian hukum normatif yang dimana penelitian dilakukan dengan mengkaji bahan-bahan hukum melalu studi kepustakaan. Pendekatan masalah yang dipergunakan merupakan pendekatan perundang-undangan (statute approach) dan pendekatan konseptual (conceptual approach). Penelitian hukum normatif ini menggunakan sumber bahan hukum primer dan sekunder. Bahan hukum primer diperoleh dari peraturan perundang-undangan seperti Undang-undang Dasar Negara Republik Indonesia Tahun 1945, Kitab Undang-undang Hukum Perdata ( KUHPerdata), Undang-undang Republik Indonesia Nomor 5 Tahun 1960 tentang Peraturan Dasar Pokok-pokok Agraria (UUPA), Undang-undang Republik Indonesia Nomor 1 Tahun 2006 tentang Kewarganegaraan Republik Indonesia, Peraturan Pemerintah Republik Indonesia Nomor 4 Tahun 1997 tentang Pendaftaran Tanah, dan Peraturan Pemerintah Republik Indonesia Nomor 103 Tahun 2015 tentang Pemilikan Rumah Tempat Tinggal 
atau Hunian oleh Orang Asing yang Berkedudukan di Indonesia. Sedangkan bahan hukum sekunder diperoleh dari sumber-sumber selain peraturan perundang-undangan, seperti buku-buku teks, kamuskamus hukum, jurnal-jurnal hukum dan komentar-komentar atas putusan pengadilan yang berkaitan dengan penelitian ini.

Teknik pengumpulan sumber bahan hukum ini yaitu dilakukan dengan klasifikasi dan metode pencatatan dengan cara mengulas, meringkas dan mengutip bahan-bahan hukum primer dan sekunder. Selain itu pengumpulan bahan-bahan hukum dilakukan dengan cara membaca buku-buku, peraturan perundang-undangan serta literatur yang sesuai dengan permasalahan yang dibahas dalam penelitian ini. Bahan-bahan hukum yang diperoleh melalui sistem studi kepustakaan selanjutnya akan dianalisis dengan menggunakan argumentasi yang akan dikaitkan dengan bahan hukum lainnya, sehingga memperoleh gambaran ataupun dapat menguatkan suatu gambaran yang telah ada sebelumnya.

\section{HASIL PENELITIAN DAN PEMBAHASAN}

\section{Pengaturan Hak atas Tanah Waris di Indonesia berdasarkan KUHPerdata}

Tanah yang terdapat di seluruh wilayah Indonesia merupakan milik Bangsa Indonesia dan dikuasai oleh Negara. Atas ketentuan inilah ditentukan adanya jenis-jenis hak atas tanah yang diberikan kepada dan dimiliki oleh seseorang, baik secara pribadi ataupun dimiliki bersama-sama dengan orang lain, serta badan hukum. Hak atas tanah adalah hak yang didapat seseorang dan memberi wewenang kepada orang tersebut untuk mempergunakan dan mengambil manfaat dari tanah itu dengan memperhatikan fungsinya. Hak atas tanah ini diatur dalam Pasal 16 Undang-undang Pokok Agraria, yakni: Hak milik, Hak Guna Usaha, Hak Guna Bangunan (HGB), Hak Pakai, Hak Sewa Untuk Bangunan, Hak Membuka Tanah dan Memungut Hasil Hutan.

Peralihan hak atas tanah menurut Peraturan Menteri Negara Agraria/Kepala Badan Pertanahan Nasional No. 9 Tahun 1999 dapat diberikan kepada Warga Negara Indonesia, Warga Negara Asing yang berkedudukan di Indonesia, Badan Hukum Indonesia, dan Badan Hukum Asing yang berkedudukan di Indonesia. Hak atas tanah dapat dialihkan melalui:

1. Jual beli tanah

Jual beli tanah tidak dijelaskan secara terperinci dalam UUPA, namun semenjak berlakunya PP No 4 Tahun 1997 tentang Pendaftaran Tanah, jual beli dilakukan dihadapan PPAT yang bertugas membuat akta. Akta jual beli ini lah yang membuktikan bahwa telah terjadi perbuatan hukum pemindahan hak dan penerima hak (pembeli) sudah menjadi pemegang hak yang baru (Sutedi, 2009: 76-77). Warga negara asing yang mengalihkan tanah hak miliknya melalui jual beli, setelah terjadinya kesepakatan dengan hak pemilih atas tanah ia dapat melakukan kesepakatan lebIh lanjut bila mana ia ingin tinggal di wilayah Indonesia. Dengan memberikan sejumlah uang yang disepakati kedua belah pihak untuk memberikan hak pakai atau hak guna bangunan atas tanah tersebut maka telah mengakibatkan adanya peralihan dari hak milik menjadi hak guna bangunan atau hak pakai.

2. Hibah tanah

Hibah tanah adalah pemberian kepada orang lain dengan suka rela tanpa ada kontraprestasi dari pihak penerima pemberian dan pemberian ini dilakukan pada saat si pemberi masih dalam keadaan hidup (Harsono, 2003: 3). Pemberian hibah tanah harus dilakukan dengan akta PPAT. Perolehan tanah hibah harus didaftarkan peralihan haknya di Kantor Pertanahan setempat untuk pengamanan hibah tanah.

3. Pewarisan

Peralihan hak karena pewarisan ditegaskan pada Bab V Paragraf 3 tentang Peralihan Hak Karena Pewarisan sebagaimana tersebut dalam Pasal 4 PP No 4 Tahun 1997, yakni: untuk peralihan bidang tanah yang sudah terdaftar, wajib menyerahkan sertifikat tanah yang bersangkutan, surat kematian orang yang namanya dicatat sebagai pemegang hak dengan surat tanda bukti sebagai ahli waris kepada Kantor Pertanahan. Apabila bidah tanah warisan belum terdaftar, wajib menyerahkan dokumen surat keterangan Kepala Desa/ Kelurahan yang menyatakan bersangkutan menguasai tanah, dan surat keterangan menyatakan bahwa bidang tanah tersebut belum bersertifikat dari Kantor Pertanahan. Apabila penerima waris satu orang, pendaftaran peralihan hak tersebut dilakukan kepada orang tersebut berdasarkan surat tanda bukti sebagai ahli waris. Namun apabila penerima waris lebih dari satu orang pendaftaran hak milik atas tanah dilakukan kepada penerima warisan yang bersangkutan berdasarkan suatu 
tanda bukti sebagai ahli waris dan akta pembagian waris. Apabila belum ada ada akta pembagian warisannya, harus didaftarkan peralihan haknya kepada para penerima warisan yang berhak sebagai hak bersama mereka berdasarkan surat tanda bukti sebagai ahli waris dan/atau akta pembagian waris tersebut.

Hak atas tanah waris di Indonesia berlaku tiga hukum waris, yakni: Hukum waris Adat, Hukum Waris Islam, dan Hukum Waris Kitab Undang-undang Hukum Perdata. Hukum Waris Adat merupakan aturan mengenai penerus harta kekayaan dari satu generasi kepada keturunannya berdasarkan pada hukum adat tiap daerah. Hukum Waris Islam adalah ketentuan yang mengatur peralihan harta kekayaan dari pewaris yang telah meninggal dunia kepada ahli waris berdasarkan pada hukum Islam hal ini diperuntukkan penganut agama Islam. Sedangkan Hukum Waris KUHPerdata merupakan ketentuan yang menganut sistem individual artinya pihak laki-laki atau perempuan mendapatkan porsi yang sama (Kuncoro, 2015: 30). Selain itu hak atas tanah waris juga diatur secara khusus dalam Undang-undang Republik Indonesia Nomor5 Tahun 1960 tentang Peraturan DasarPokok-pokok Agraria yang selanjutnya disebut dengan UUPA. Bagi seorang ahli waris berupa tanah harus melegalisasikan hak atas tanah tersebut dengan mengikuti persyaratan yang diatur dalam Peraturan Pemerintah Nomor 4 Tahun 1997 tentang Pendaftaran Tanah.

Warga negara dan kewarganegaraan diatur dalam Undang-undang Republik Indonesia Nomor 1 Tahun 006 tentang Kewarganegaraan Republik Indonesia. Warga negara Indonesia merupakan orang-orang bangsa Indonesia asli dan orang-orang bangsa lain yang disahkan dengan undangundang sebagai warga Negara. Hal ini sesuai dengan apa yang tercantum dalam asal UU RI No. 1 Tahun 2006. Orang bangsa Indonesia asli ialah orang yang memiliki garis keturunan darah dan genetika asli bangsa Indonesia, sedangkan orang-orang bangsa lain yang dimaksud adalah orang yang berasal dari wilayah lain dan menetap di Indonesia yang telah tercatat dan disahkan dengan undangundang sebagai warga negara Indonesia.

Warga negara asing adalah seseorang yang sementara waktu atau tetap bertempat tinggal di negara tertentu tidak berkedudukan sebagai warga negara dan tidak secara resmi terdaftar sebagai warga negara tidak secara resmi terdaftar sebagai warga negara. Dalam Pasal 7 UU RI No. 1 Tahun 2006 menyebutkan setiap orang yang bukan Warga Negara Indonesia diperlakukan sebagai orang asing, yang dimana berarti warga negara asing di Indonesia adalah warga negara yang bukan merupakan warga negara Indonesia yang sedang berada di Indonesia (Supramono, 2014:4-5).

Seorang ahli waris dalam mendapatkan waris tanahnya harus sesuai dengan golongan. Hal ini mengacu kepada Hukum Waris KUHPerdata, golongan ini meliputi:

1. Golongan pertama, yakni suami atau istri serta anak-anak pewaris hingga keturunannya dalam garis keturunan kebawah masing-masing mendapatkan 1/4 (seperempat) bagian dari seluruh harta warisan yang ditinggalkan. Hal ini sesuai dengan Pasal 852 KUHPerdata.

2. Golongan kedua, ialah orang tua dan saudara atau saudari dari pewaris apabila pewaris belum memiliki suami atau istri dan anak, pembagian warisan sebesar 1/4 (seperempat) bagian dari keseluruhan jumlah warisan. Pada prinsipnya orang tua tidak boleh kurang dari 1/4 (seperempat) bagian. Hal ini sesuai dengan Pasal 854 KUHPerdata. Di dalam Pasal 855 KUHPerdata, apabila pewaris meninggalkan seorang saudara laki-lakI dan seorang saudara perempuan, hak dari bapak atau ibu yang hidup terlama adalah setengah (1/2) bagian. Tetapi, apabila pewaris meninggalkan dua orang saudara laki-laki atau saudara perempuan, yang menjadi hak dari bapak dan ibu yang hidup terlama adalah sepertiga (1/3) bagian. Namun apabila pewaris meninggalkan lebih dari dua saudara laki-laki atau saudara perempuan, yang menjadi hak dari bapak dan ibu yang hidup terlama adalah seperempat (1/4) bagian. Pasal 856 KUHPerdata menentukan bahwa apabila orang tua meninggal lebih dulu maka saudara sekandung yang mewaris. Dalam Pasal 857 KUHPerdata diatur dengan ketentuan istimewa yaitu warisan dibagi dua lebih dahulu, separuh bagian untuk saudara-saudara satu ibu dan separuh lagi untuk saudara satu ayah sekandung, seorang saudara sekandung (satu ayah satu ibu) mendapatkan dari kedua bagian tersebut.

3. Golongan ketiga, keluarga sedarah dalam garis lurus keatas yakni kakek dan nenek dari pihak ayah dan ibu berdasarkan pada ketentuan Pasal 853 KUHPardata. Golongan ketiga ini dapat mewaris apabila ahli waris golongan pertama dan golongan kedua tidak ada.

4. Golongan keempat, keluarga dari garis keturunan kesamping sampai derajat keenam dihitung dari pewaris, hal ini diatur dalam Pasal 858 KUHPerdata. Dalam Pasal 861 KUHPerdata 
menegaskan kembali bahwa keluarga sedarah yang hubungannya dengan pewaris lebih jauh dari derajat keenam dalam garis keturunan kesamping maka ia tidak berhak mewaris. Berdasakan Pasal 83 KUHPerdata apabila menurut pasal-pasal dalam KUHPerdata tersebut sama sekali tidak terdapat ahli waris yang berhak memiliki atas warisan, maka harta warisan jatuh dan menjadi milik negara serta negara juga berkewajiban untuk membayar hutang-hutang si pewaris selagi harta warisan mencukupi untuk itu.

\section{Kedudukan Hak atas Tanah Waris WNI yang Berpindah Kewarganegaraan}

Ada beberapa hal yang dapat menggugurkan hak seseorang untuk mewarisi peninggalan si pewaris. Hal ini diatur dalam Pasal 838 KUHPerdata, yakni: Mereka yang telah dihukum karena dipersalahkan telah membunuh atau mencoba membunuh atau menganiaya berat si pewaris, mereka dengan putusan hakim pernah dipersalahakan karena memfitnah telah mengajukan tuduhan terhadap si pewaris yang diancam dengan hukuman 5 tahun penjara atau hukuman yang lebih berat, mereka yang dengan kekerasan atau perbuatan nyata mencegah atau menghalangi si pewaris untuk membuat atau mencabut kembali surat wasiatnya, mereka yang telah menggelapkan, memusnahkan, serta memalsukan surat wasiat yang dibuat oleh pewaris.

Seorang ahli waris yang ditunjuk dalam suratwasiat (testament) yang dibuatoleh pewaris berupa pemberian harta peninggalan sebidang tanah, maka tanah tersebut diterima oleh ahli waris sebesar atau sejumlah yang tertera dalam isi surat wasiat atau testament tersebut. Surat wasiat atau testament dapat batal apabila orang yang menerima wasiat meninggal lebih dahulu sebelum orang yang mewasiatkan meninggal dunia, hal ini tercantum dalam pasal 997 KUHPerdata. Surat wasiat dapat batal pula apabila orang yang menerima wasiat atau testament menolak atau ternyata ia tidak cakap untuk menerimanya. Hal ini tercantum dalam Pasal 1001 KUHPerdata.

Pembagian hak atas tanah waris warga negara Indonesia yang ditinggalkan oleh pewaris untuk ahli waris berupa tanah namun setelahnya merubah kewarganegaraan, maka terdapat beberapa ketentuan yang harus dijalani berkaitan dengan UUPA. Dengan berpindahnya kewarganegaraan akan berdampak pada hilangnya hak milik atas tanah namun dalm hal waris sedikit berbeda. Larangan kepemilikan tanah oleh WNI yang berpindah kewarganegaraan bukan menyebabkan hak warisnya tersebut gugur, solusinya ahli waris dapat memperoleh ganti dalam bentuk uang tunai atau hasil penjualan atas tanah waris, hal ini berdasarkan ketentuan Pasal 1 ayat (3) UUPA.

Dalam jangka waktu satu tahun orang yang telah merubah kewarganegaraannya sudah harus melakukan pengalihan atas tanah yang diwarisi, jika tidak tanah tersebut akan jatuh kepada negara. Pengalihan hak milik tanah yang diwarisi dapat dilakukan dengan meminta kepada Badan Pertanahan Nasional agar tanah tersebut statusnya diturunkan menjadi hak pakai, menghibahkan kepada subjek hak milik lain, atau dengan menjual tanah tersebut.

Status hak atas tanah waris bagi warga negara Indonesia yang beralih kewarganegaraan tersebut ialah berstatus hak pakai, bilamana ia mengalihkan hak milik atas tanahnya menjadi hak pakai agar ia tetap dapat menggunakan tanahnya dengan status hak pakai atas tanah.

\section{SIMPULAN DAN SARAN}

\section{Simpulan}

Berdasarkan pada teori dan aturan hukum yang sudah dijelaskan, maka dapatditarik kesimpulansebagai berikut: Pengaturan hak atas tanah waris di Indonesia yaitu berlakunya tiga hukum waris yang meliputi Hukum Waris Adat, Hukum Waris Islam, dan Hukum Waris KUHPerdata. Berdasarkan pada Hukum Waris KUHPerdata pembagian warisnya meliputi adanya penggolongan ahli waris dan surat wasiat. Tiap golongan mendapatkan bagian yang sama, namun golongan terdahulu akan menutup golongan yang berikutnya serta pembagian waris menurut surat wasiat ialah berdasarkan pada isi surat wasiat yang mana isi dari surat wasiat tidak boleh bertentangan dengan legitieme portie atau bagian mutlah ahli waris. Bila membahas mengenai objek dari suatu waris adalah tanah maka ada ketentuan lain yang perlu dipatuhi, aturan tersebut ialah Undang-undang Republik Indonesia Nomor 5 Tahun 1960 tentang Peraturan Dasar Pokok-Pokok Agraria. Ketentuan dalam hukum waris KUHPerdata harus berkesinambungan dengan ketentuan UUPA, jika yang mendapatkan waris berupa tanah ialah warga negara asing, sebagaimana yang tercantum dalam Pasal1 ayat(3) maka orangasing tersebut harus mengalihkan hak milik atas tanahnya dalam jangka waktu 
satu tahun sejak diberikannya warisan tersebut. Dapat ditarik simpulan bahwa pengaturan mengenai hak atas tanah waris di wilayah Indonesia berkaitan satu sama lain, yang mana kaitan antara aturanaturan tersebut akan berpengaruh pada implementasinya di masyarakat.

Kedudukan hak atas tanah waris warga negara Indonesia yang beralih kewarganegaraan ialah tanahnya akan jatuh pada negara bilamana ia tidak mengalihkan atau menjual hak milik atas tanah warisnya kepada subjek hak milik dalam kurun waktu satu tahun, ini sesuai dengan isi pada Pasal 1 ayat (3) UUPA, sehingga status hak atas tanah waris bagi warga negara Indonesia yang berpindah kewarganegaraan tersebut dapat beralih menjadi hak pakai, bilamana ia mengalihkan hak milik atas tanahnya menjadi hak pakai dengan cara melepasakan status hak milik atas tanah warisnya kepada negara dan selanjutnya mengajukan permohonan pada Badan Pertanahan Nasional, namun apabila ia menjual, menghibahkan tanah warisnya maka kedudukan hak milik atas tanah waris tersebut akan beralih kepada pembeli tanah waris tersebut.

\section{Saran}

Melihat dari simpulan yang ada, penulis mempunyai saran yang berkaitan dengan kedudukan hak atas tanah waris warga negara Indonesia yang berpindah kewarganegaraan, yaitu untuk adanya kepastian dan perlindungan hukum perihal hak atas tanah waris yang dimiliki oleh warga negara asing berdasarkan Pasal 1 ayat (3) UUPA ini berkaitan dengan jangka waktu yang diberikan, hendaknya pemerintah memudahkan warga negara Indonesia yang berpindah kewarganegaraan dengan memberikan batas waktu minimum dan maksimum dalam peralihan hak atas tanah waris tersebut mengingat banyak prosedur yang harus dilalui dalam proses pengalihan hak atas tanah serta menjual tanah untuk saat ini dirasa lumayan sulit melihat pada perekonomian masyarakat, karena aturan ini tentunya diharapkan bagi masyarakat khususnya warga negara Indonesia yang berpindah kewarganegaraan dapat membuatnya merasa dilindungi hak-haknya khususnya hak atas tanah di wilayah Indonesia.

\section{DAFTAR PUSTAKA}

Harsono, B. (2003). Undang-Undang Pokok Agraria. Kelompok Belajar "ESA".

Irvan, M., Warman, K., \& Arnetti, S. (2019). Proses Peralihan Hak Milik atas Tanah Karena Pewarisan dalam Perkawinan Campuran. LamLaj, 4(2), 148-161.

Kuncoro, W. (2015). Waris: Permasalahan dan Solusinya. Raih Asa Sukses.

Paramita, I. A. I. D., Yusa, I. G., \& Wiryawan, I. W. (2018). Hak Ahli Waris Berkewarganegaraan Asing terhadap Harta Warisan Berupa Tanah. Kertha Semaya, 6(2), 1-5.

Sajad, H. (2008). Pelaksanaan Pendaftaran Peralihan Hak Milik atas Tanah karena Pewarisan di Kecamatan Rembang Kabupaten Rembang [Universitas Diponegoro].

Santoso, U. (2015). Perolehan Hak atas Tanah. Prenadamedia Group.

Supramono, G. (2014). Hukum Orang Asing di Indonesia. Jakarta.

Sutedi, A. (2009). Peralihan Hak atas Tanah dan Pendaftarannya (1st ed.). Sinar Grafika.

Widanarti, H. (2018). Akibat Hukum Perkawinan Campuran terhadap Harta Perkawinan (Penetapan Pengadilan Negeri Denpasar No: 536/Pdt.P/2015/PN.Dps.). Diponegoro Private Law Review, 2(1), 161-169.

Winarta, E. N., Wairocana, I. G. N., \& Sarjana, I. M. (2017). Hak Pakai atas Rumah Hunian Warga Negara Asing dalam Perkawinan Campuran tanpa Perjanjian Kawin. Jurnal Ilmiah Prodi Magister Kenotariatan, 2(1), 42-57.

Kitab Undang-undang Hukum Perdata (KUHPerdata).

Undang-undang Republik Indonesia Nomor 5Tahun 1960 tentang Peraturan Dasar Pokok-pokok Agraria.

Undang-undang Republik Indonesia (RI) Nomor 1 Tahun 2006 tentang Kewarganegaran Republik Indonesia.

Peraturan Pemerintah Republik Indonesia Nomor 40 Tahun 1996 tentang Hak Guna Usaha, Hak Guna Bangunan dan Hak Pakai Atas Tanah.

Peraturan Pemerintah Republik Indonesia Nomor 4 Tahun 1997 tentang Pendaftaran Tanah.

Peraturan Pemerintah Republik Indonesia Nomor 103 Tahun 2015 tentang Pemilikan Rumah Tempat Tinggal atau Hunian Oleh Orang Asing yang Berkedudukan di Indonesia. 
Jurnal Interpretasi Hukum

Vol. 1, No. 1 2020, Hal. 30-36

Peraturan Menteri Negara Agraria/ Kepala Badan Pertanahan Nasional Nomor 9 Tahun 1999 tentang Tata Cara Pemberian dan Pembatalan Hak atas Tanah Negara dan Hak Pengelolaan. 